\title{
Altitudinal Variation in Soil physico-chemical properties of a Western Himalayan Forest, Uttarakhand, India
}

\author{
Vinay Rawat ${ }^{1 *} \cdot$ Ajendra Singh Bagri ${ }^{1} \bullet$ Hardeep Singh $^{1} \bullet$ Prabhawati Tiwari $^{1} \bullet$ Jay Krishan $^{\prime}$ \\ Tiwari $^{1}$ \\ ${ }^{1}$ Department of Botany and Microbiology, HNB Garhwal University, Srinagar (Garhwal), 246174, \\ Uttarakhand, India
}

*Corresponding author: vinayrwt14@gmail.com

Received: 30.8.2021; Revised: 11.11.2021; Accepted: 13.11.2021

CSociety for Himalayan Action Research and Development

\begin{abstract}
The physico-chemical properties of soil vary with the variation in the topographic features, climatic conditions and forest types. In any forest ecosystem, both vegetation and soil influence each other through nutrient cycles. The altitudinal variation in soil physico-chemical properties was analyzed in a temperate forest (Radi forest) of Upper Yamuna Forest Division in Uttarkashi district of Uttarakhand (Western Himalaya, India). A total of three forest sites were selected at different altitudes (the lower, middle, and upper) to collect composite soil samples from each site covering $0-10 \mathrm{~cm}, 11-20 \mathrm{~cm}$ and $21-30 \mathrm{~cm}$ depths. The textural class of the soils was sandy loam. The colour of the soil samples varied from brown to very dark brown. The water holding capacity $(r=0.994)$, soil organic carbon $(r=0.967)$, organic matter $(r=0.966)$, nitrogen $(r=0.993)$, phosphorus $(\mathrm{r}=0.982)$ and potassium content $(\mathrm{r}=0.994)$ had positive correlation with altitude whereas negative correlation was observed between altitude and soil $\mathrm{pH}(\mathrm{r}=-0.983)$ in the study. The present study concludes that soil physico-chemical properties in temperate forests of Uttarakhand Himalaya vary significantly with variation in altitude.
\end{abstract}

Keywords: Altitudinal gradient; Composite soil sample; Physico-chemical properties; Soil analysis; Temperate forest.

\section{Introduction}

Soil is one of the basic natural resources on which all terrestrial life forms co-exist. It plays a vital role in maintaining the productivity and sustainability of forest ecosystems (Tiwari 2005). Soil and forest together constitute an important support system of our life. The organic matter and nutrients are of basic importance in the study of soil as they are responsible for its various physical and chemical properties and ultimately influence the vegetation (Jha et al 1984). The nature of soil profile and nutrient cycling between the soils and plants are the essential dimensions to determine the quality of a forest. The growth and reproduction of forests cannot be understood without the knowledge of soil (Miller and Donahue 1990). Forest soil influences many forest attributes like composition of the forests, rate of tree growth, efficacy of natural reproduction, etc. (Bhatnagar 1965). Also, the underground life of a forest is the key to an adequate understanding of its above surface life. Hence, the knowledge of soils properties is essential to understand the forest community dynamics and plan management strategies. 
In the present study, we have investigated the soil physico-chemical properties (texture, colour, moisture content, water holding capacity, $\mathrm{pH}$, organic carbon, organic matter, total nitrogen, available phosphorus and potassium) across the elevation gradient in a temperate forest (Radi forest) of Upper Yamuna Forest Division in Uttarkashi district of Uttarakhand, Western Himalaya, India.

\section{Materials and methods}

\section{Study area}

The present study was carried out to analyse soil physico-chemical properties at three different altitudes in the Radi forest $\left(30^{\circ} 46^{\prime} 16.6^{\prime \prime} \mathrm{N}\right.$ to $30^{\circ} 46^{\prime} 42.5^{\prime \prime} \mathrm{N}$ and $78^{\circ} 14^{\prime} 21.6^{\prime \prime} \mathrm{E}$ to $78^{\circ} 15^{\prime} 45^{\prime \prime} \mathrm{E}$ ) of Upper Yamuna Forest Division in district
Uttarkashi, Uttarakhand (Fig. 1). This forest has thick tree cover of Quercus leucotrichophora in association with Rhododendron arboreum, Lyonia ovalifolia, Cedrus deodara, Quercus floribunda, Pinus wallichiana, etc. (Fig. 2). Three forest sites were selected and based on altitude were classified as lower (R1), middle (R2), and upper (R3) (Table 1). The texture of the soil was predominantly sandy loam, and the soil was acidic. The area has three major seasons, viz., cold and dry winter (December to February), warm and dry summer (April to mid-June) and rainy (mid-June to September), whereas spring (February to March) and autumn (October to November) are transition periods. Snowfall occurs during January and February.

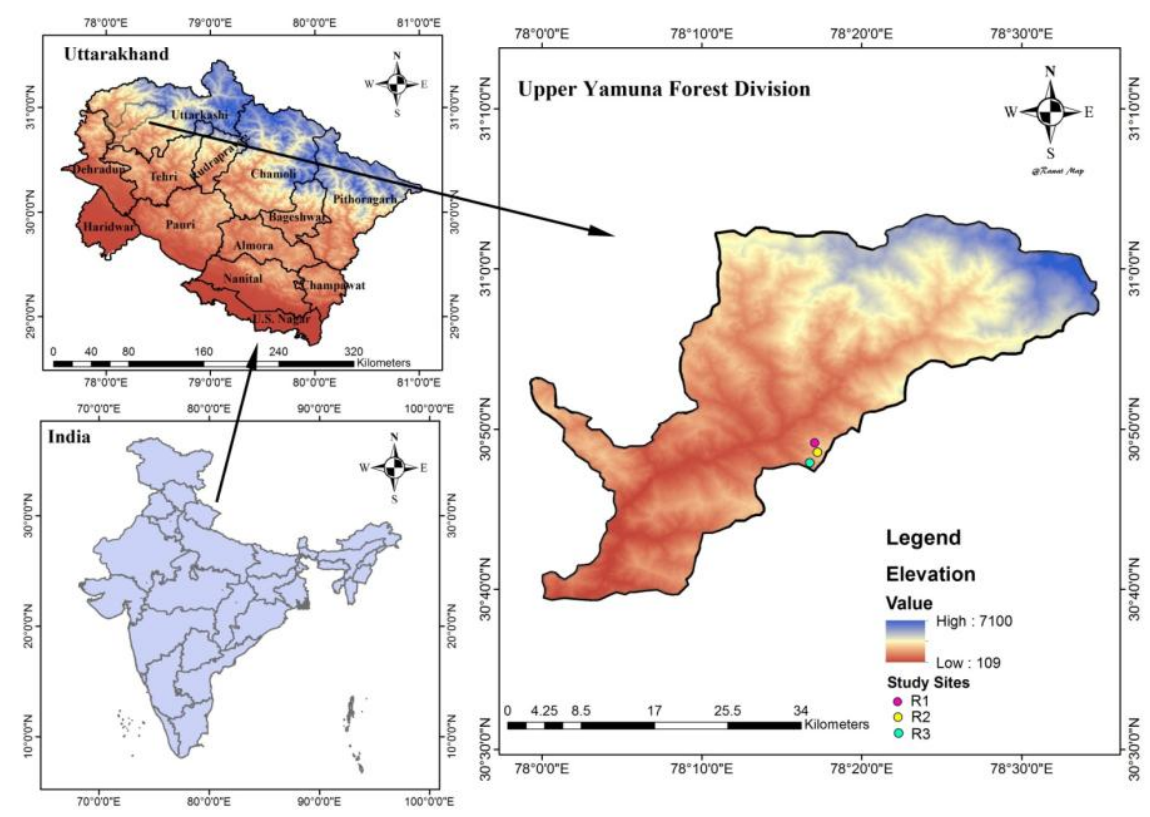

Figure 1: Map showing the location of study area and the sites (R1, R2 and R3). 

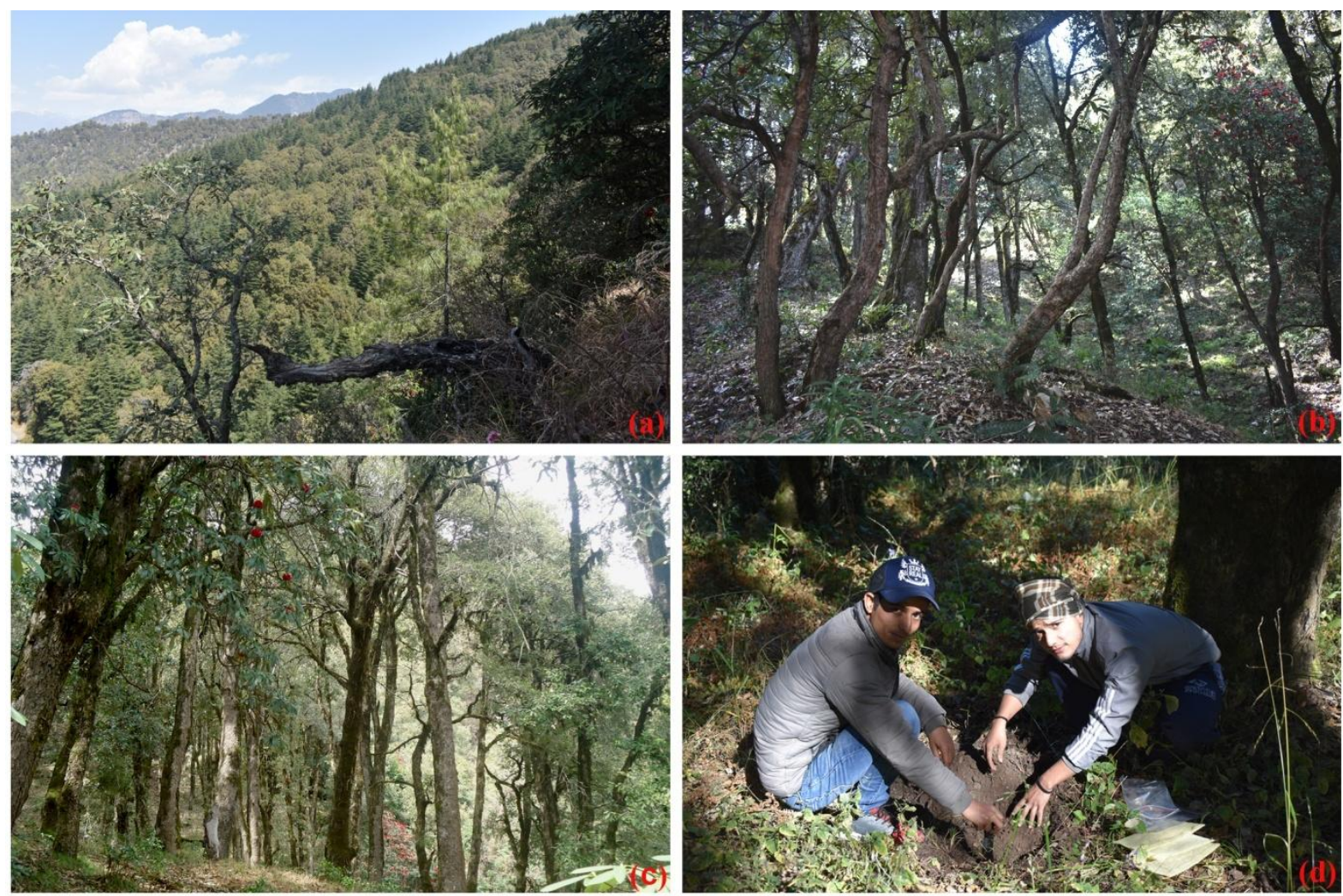

Figure 2: a. Radi forest in Uttarkashi, b, c. Broad leaved forest stands in Radi forest, and d. Collection of soil samples during the field visit.

Table 1: Description of the study sites in Radi forest of Upper Yamuna Forest Division (Uttarkashi, Uttarakhand).

\begin{tabular}{llllll}
\hline S. No. & Site (code) & Altitude (m asl) & Latitude & Longitude & Aspect* \\
\hline 1 & Lower (R1) & 1800 & $30^{\circ} 46^{\prime} 42.5^{\prime \prime} \mathrm{N}$ & $78^{\circ} 15^{\prime} 43.5^{\prime \prime} \mathrm{E}$ & $\mathrm{N}$ \\
2 & Middle (R2) & 2100 & $30^{\circ} 46^{\prime} 36^{\prime \prime} \mathrm{N}$ & $78^{\circ} 15^{\prime} 45^{\prime \prime} \mathrm{E}$ & $\mathrm{NW}$ \\
3 & Upper (R3) & 2400 & $30^{\circ} 46^{\prime} 16.6^{\prime \prime} \mathrm{N}$ & $78^{\circ} 14^{\prime} 21.6^{\prime \prime} \mathrm{E}$ & $\mathrm{NE}$
\end{tabular}

${ }^{*} N=$ North, $N W=$ Northwest, $N E=$ North East.

\section{Methodology}

The soil samples were collected from each forest at three depths, viz. $0-10 \mathrm{~cm}, 11-20$ $\mathrm{cm}$, and 21-30 $\mathrm{cm}$. The composite soil samples were prepared by mixing five samples of each depth taken randomly from different places in the forest (Fig. 2).
The samples were tightly packed in plastic bags with field details and brought to the laboratory for further analysis. The physical properties like moisture content, water holding capacity, colour and texture were analyzed in the Botany Research Laboratory at Department of Botany and 
Microbiology, HNB Garhwal University, Srinagar (Garhwal). The chemical properties like $\mathrm{pH}$, organic carbon, organic matter, total nitrogen, available phosphorus and potassium were analyzed in the Soil Laboratory of Forest Ecology and Climate Change Division, Forest Research Institute, Dehradun.

\section{Physical properties}

The soil texture was determined using sieves of different pore sizes following Pandeya et al. (1968), and the USDA textural triangle was used to identify the texture classes. The soil colour was determined with the help of Munsell soil colour chart. Misra (1968) was followed to determine the water holding capacity of the soil samples.

Water Holding Capacity $(W H C)=\frac{W_{2}-W_{3}}{W_{3}-W_{1}} \times 100$

where $\mathrm{W}_{1}=$ Weight of empty crucible; $\mathrm{W}_{2}=$ Weight of crucible with wet (saturated soil); $\mathrm{W}_{3}=$ Weight of crucible with dry soil.

The method suggested by Miller and Donahue (1990) was used to determine the per cent of moisture content in soil.

Moisture Content $(\%)=\frac{\text { Weight of moist soil }- \text { Weight of oven dry soil }}{\text { Weight of oven dry soil }} \times 100$

\section{Chemical properties}

The digital $\mathrm{pH}$ meter was used to measure the soil $\mathrm{pH}$. The rapid titration method of Walkley (1947) was used to calculate the per cent of soil organic carbon present in the soils. The soil organic matter (\%) was calculated using the factor of 1.724 of organic carbon (\%). Olsen et al. (1954) was followed to calculate the available phosphorus. Ammonium acetate method of Morwin and Peach (1951) was used to extract potassium, and then estimation was done by using flame photometer. Estimation of total nitrogen was done following Kjeldhal procedure given by Bremner and Mulvaney (1983).

\section{Results}

In the present study, hue was 7.5YR for the soil samples, value ranged from 2.5 to 4, and chroma varied between 2 and 4 (Table 2). The soil colour ranged from brown to very dark brown. The texture of soils was sandy loam throughout the study sites (Table 3). The values for water holding capacity (WHC) decreased with increase in soil depth at all the sites. The WHC ( $\mathrm{r}=0.994)$ was found to be positively correlated with the altitude (Fig. 3). The soil moisture was negatively correlated with the altitude. 
Table 2: Variation in soil colour along the altitudinal gradient in the study area.

\begin{tabular}{lllll}
\hline S. No. & Site & Hue & Value/Chroma & Colour \\
\hline 1 & R1 & $7.5 Y R$ & $4 / 4$ & Brown \\
2 & R2 & $7.5 Y R$ & $3 / 3$ & Dark brown \\
3 & R3 & $7.5 Y R$ & $2.5 / 2$ & Very dark brown \\
\hline
\end{tabular}

Table 3: Physical properties of soil along different altitudes and depths.

\begin{tabular}{llllllll}
\hline Site & $\begin{array}{l}\text { Depth } \\
(\mathbf{c m})\end{array}$ & WHC $(\boldsymbol{\%})$ & MC $(\%)$ & Sand $(\%)$ & Silt $(\boldsymbol{\%})$ & Clay (\%) & Textural class \\
\hline R1 & $0-10$ & 59.80 & 19.27 & 64.56 & 30.35 & 5.09 & Sandy loam \\
& $11-20$ & 53.42 & 21.13 & 64.97 & 29.15 & 5.88 & \\
& $21-30$ & 49.13 & 23.08 & 64.51 & 29.46 & 6.03 & \\
& Mean \pm SD & $\mathbf{5 4 . 1 2} \pm \mathbf{5 . 3 7}$ & $\mathbf{2 1 . 1 6} \pm \mathbf{1 . 9 1}$ & $\mathbf{6 4 . 6 8} \pm \mathbf{0 . 2 5}$ & $\mathbf{2 9 . 6 5 \pm \mathbf { 0 . 6 2 }}$ & $\mathbf{5 . 6 7} \pm \mathbf{0 . 5 1}$ & \\
\hline R2 & $0-10$ & 62.79 & 17.14 & 50.46 & 40.25 & 9.25 & Sandy loam \\
& $11-20$ & 58.64 & 16.56 & 51.09 & 39.83 & 9.08 & \\
& $21-30$ & 54.07 & 18.23 & 51.71 & 40.16 & 8.13 & \\
& Mean \pm SD & $\mathbf{5 8 . 5 0} \pm \mathbf{4 . 3 6}$ & $\mathbf{1 7 . 3 1} \pm \mathbf{0 . 8 5}$ & $\mathbf{5 1 . 0 9} \pm \mathbf{0 . 6 3}$ & $\mathbf{4 0 . 2 1} \pm \mathbf{0 . 0 6}$ & $\mathbf{8 . 8 2} \pm \mathbf{0 . 6 0}$ & \\
\hline R3 & $0-10$ & 65.89 & 13.45 & 64.76 & 26.53 & 8.71 & Sandy loam \\
& $11-20$ & 61.56 & 15.31 & 65.21 & 26.91 & 7.88 & \\
& $21-30$ & 57.04 & 17.05 & 65.91 & 27.05 & 7.04 & \\
& Mean \pm SD & $\mathbf{6 1 . 5 0} \pm \mathbf{4 . 4 3}$ & $\mathbf{1 5 . 2 7} \pm \mathbf{1 . 8 0}$ & $\mathbf{6 5 . 2 9} \pm \mathbf{0 . 5 8}$ & $\mathbf{2 6 . 8 3} \pm \mathbf{0 . 2 7}$ & $\mathbf{7 . 8 8 \pm \mathbf { 0 . 8 4 }}$ & \\
\hline
\end{tabular}
Abbreviations used: $W H C=$ Water holding capacity; $M C=$ Moisture content.

The values for total nitrogen $(\mathrm{N})$, available phosphorus $(\mathrm{P})$, available potassium $(\mathrm{K})$, organic carbon (OC), soil organic matter (SOM) and $\mathrm{pH}$ across the study sites ranged from $0.27 \pm 0.04$ to $0.37 \pm 0.04 \%$, $27.56 \pm 2.69$ to $31.98 \pm 3.88 \mathrm{~kg} \mathrm{ha} \mathrm{ha}^{-1}$, $127.31 \pm 27.44$ to $198.03 \pm 36.03 \mathrm{~kg} \mathrm{ha}{ }^{-1}$, $1.32 \pm 0.39$ to $2.57 \pm 0.52 \%, 2.38 \pm 0.66$ to $4.44 \pm 0.90 \%$ and $5.21 \pm 31$ to $6.12 \pm 0.30$ respectively (Table 4). The soil of all the forest sites was acidic. The OC $(r=0.967)$ and SOM $(r=0.966)$ were positively correlated with altitude and had a negative relationship with soil depth. In contrast, the $\mathrm{pH}(\mathrm{r}=-0.983)$ showed a negative correlation with altitude and had a positive relationship with depth. The total $\mathrm{N}(\mathrm{r}=$ 0.993) and available $\mathrm{K}(\mathrm{r}=0.994)$ were positively correlated with altitude and had a negative relationship with depth. The available $\mathrm{P}(\mathrm{r}=0.982)$ showed a positive correlation with altitude and did not show any fixed trend with depth (Fig. 3). 
Table 4: Chemical properties of soil along different altitudes.

\begin{tabular}{|c|c|c|c|c|c|c|c|}
\hline Site & $\begin{array}{c}\text { Depth } \\
\text { (cm) }\end{array}$ & pH & OC (\%) & $\operatorname{SOM}(\%)$ & $\mathbf{N}(\%)$ & $\mathbf{P}\left(\mathrm{kg} \mathrm{ha}^{-1}\right)$ & $\mathrm{K}\left(\mathrm{kg} \mathrm{ha}^{-1}\right)$ \\
\hline \multirow[t]{4}{*}{$\mathbf{R 1}$} & $0-10$ & 5.81 & 1.73 & 2.98 & 0.31 & 30.11 & 154.56 \\
\hline & $11-20$ & 6.14 & 1.27 & 2.19 & 0.27 & 27.81 & 127.69 \\
\hline & $21-30$ & 6.41 & 0.96 & 1.66 & 0.24 & 24.75 & 99.68 \\
\hline & Mean \pm SD & $6.12 \pm 0.30$ & $1.32 \pm 0.39$ & $2.28 \pm 0.66$ & $0.27 \pm 0.04$ & $27.56 \pm 2.69$ & $127.31 \pm 27.44$ \\
\hline \multirow[t]{4}{*}{$\mathbf{R 2}$} & $0-10$ & 5.40 & 2.16 & 3.72 & 0.36 & 25.26 & 224.12 \\
\hline & $11-20$ & 5.71 & 1.65 & 2.84 & 0.33 & 28.83 & 157.44 \\
\hline & $21-30$ & 6.13 & 1.17 & 2.02 & 0.29 & 33.03 & 126.36 \\
\hline & Mean \pm SD & $5.75 \pm 0.37$ & $1.66 \pm 0.50$ & $2.86 \pm 0.85$ & $0.33 \pm 0.04$ & $29.04 \pm 3.89$ & $169.31 \pm 49.95$ \\
\hline \multirow[t]{3}{*}{$\mathbf{R 3}$} & $0-10$ & 4.90 & 3.04 & 5.24 & 0.41 & 35.46 & 235.03 \\
\hline & $11-20$ & 5.22 & 2.67 & 4.60 & 0.37 & 32.68 & 196.01 \\
\hline & $21-30$ & 5.51 & 2.01 & 3.47 & 0.34 & 27.80 & 163.05 \\
\hline
\end{tabular}

$\begin{array}{lllllll}\text { Mean } \pm \text { SD } & 5.21 \pm 0.31 & 2.57 \pm 0.52 & 4.44 \pm 0.90 & 0.37 \pm 0.04 & 31.98 \pm 3.88 & 198.03 \pm 36.03\end{array}$

Abbreviations used: $O C=$ Organic carbon; $S O M=$ Soil organic matter; $N=$ Nitrogen $; K=$ Potassium; $P=$ Phosphorus.

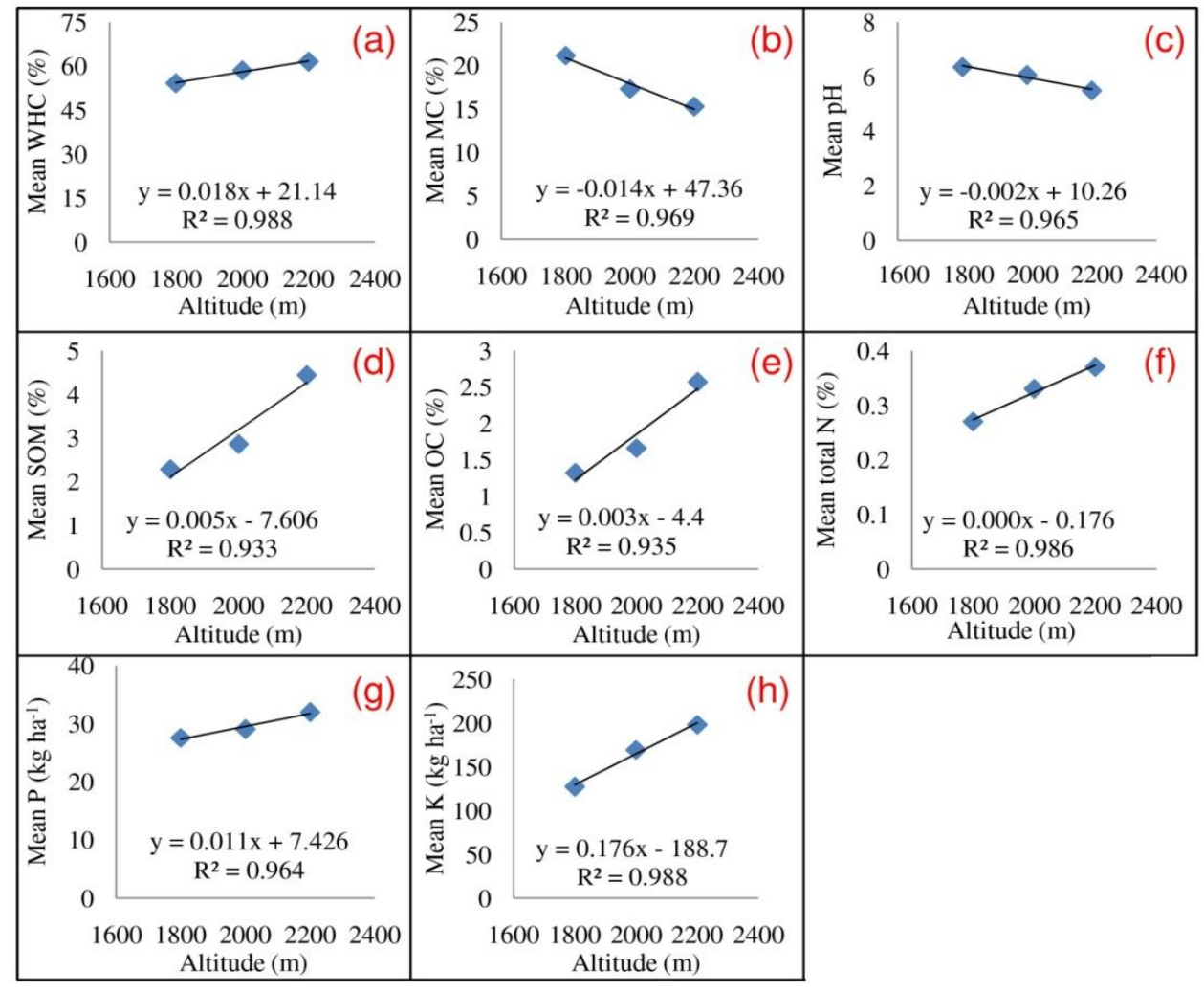

Figure 3: Correlation of different soil parameters with altitude in the study area; a. Water holding capacity (WHC); b. Moisture content (MC); c. pH; d. Soil organic matter (SOM); e. Organic carbon (OC); f. total Nitrogen $(\mathrm{N})$; g. available Phosphorus (P), and h. available Potassium (K).

\section{Discussion}


In the present study, soil colour varied from brown to dark brown (Table 2). Saha et al. (2018) and Thakur and Bisht (2020) reported a similar soil colour pattern in temperate forests from Tehri Garhwal and Himachal Pradesh respectively. The mean values of WHC for different sites were within the range of 54.12 to $61.50 \%$, and were comparable to the values reported by Kumar et al. (2013) and Saha et al. (2018) from temperate forests of Pauri Garhwal and Tehri Garhwal respectively. The sandy loam textural class of soil was similar, as reported in the earlier investigation by Sheikh and Kumar (2010) in a temperate forest from Tehri Garhwal. The mean per cent value of SOM ranged from 2.38 to 4.44, which was similar to the earlier reported values by Sheikh and Kumar (2010), Gairola et al. (2012) and Kumar et al. (2013) from the temperate forests of Garhwal Himalaya. The mean per cent value of OC in the present study varied from 1.32 to $2.57 \%$. These values were within the range reported by Sharma et al. (2010) from Buvakhal, Pauri Garhwal and Gairola et al. (2012) from Chamoli Garhwal. The available K varied between $127 \mathrm{~kg} \mathrm{ha}^{-1}$ and $198 \mathrm{~kg} \mathrm{ha}^{-1}$, similar to the values reported by Semwal (2006) from Pauri Garhwal and Sheikh and Kumar (2010). The available $P$ recorded was in the range of 27.56 to $31.98 \mathrm{~kg} \mathrm{ha}$, comparable to reported values by Rawat $e t$ al. (2020) from montane forests of western Ramganga Valley, district Chamoli (Uttarakhand).

A negative correlation between soil $\mathrm{pH}$ and increasing altitude has been reported by Thakur and Bisht (2020) in a temperate forest from Himachal Pradesh. Similar trend was observed in the present investigation. In the present study a positive correlation has been observed between soil total nitrogen, organic carbon, water holding capacity and soil organic matter, which is in accordance with the reported values of Ram et al. (2015) from a temperate forest in Central Nepal, but in contrast to their findings a negative correlation has been found between soil moisture and altitude. An increase in soil organic matter has been observed with increase in altitude (Fig. 3), which can be attributed to slow decomposition process of organic remains at higher altitudes.

It can be concluded from the present results that the altitude has a significant impact on certain physico-chemical properties of soil in temperate forests of Uttarakhand, Western Himalaya.

\section{Acknowledgements}

The authors sincerely acknowledge the Head, Department of Botany \& Microbiology, HNB Garhwal University 
Srinagar (Garhwal) for providing necessary facilities and support; Head, Forest Ecology and Climate Change Division, Forest Research Institute (Dehradun) for laboratory facility; University Grants Commission, New Delhi, for providing financial support in the form of research fellowship (VR and HS); Forest Department of Uttarakhand for granting permission to conduct fieldwork in the study area, and Dr. Dinesh Singh Rawat for his critical comments.

\section{References}

Bhatnagar HP (1965) Soils from different quality Sal (Shorea robusta) forests of Uttar Pradesh. Trop. Ecol. 6: 56-62.

Bremner JM and Mulvaney CS (1983) Nitrogen-Total. In: Page AL (Ed.), Methods of Soil Analysis: Part 2 Chemical and Microbiological Properties. American Society of Agronomy and Soil Science Society of America. pp. 595-624.

Gairola S, Sharma CM, Ghildiyal SK and Suyal S (2012) Chemical properties of soils in relation to forest composition in moist temperate valley slopes of Garhwal Himalaya,
India. Environmentalist 32

(4):

512-523.

Jha MN, Rathore RK and Pande P (1984) Soil factor affecting the natural regeneration of silver fir and spruce in Himachal Pradesh. Indian For. 110 (3): 293-298.

Kumar M, Singh H, Bhat JA and Rajwar GS (2013) Altitudinal variation in species composition and soil properties of Banj Oak and Chir Pine dominated forests. J. For. Environ. Sci. 29 (1): 29-37.

Miller RW and Donahue RL (1990) Soils: An Introduction to Soils and Plant Growth (6 ${ }^{\text {th }}$ Edition). PrenticeHall International Inc.

Misra R (1968) Ecology Workbook. Oxford and IBH Publication Company, Culcutta, India.

Morwin HD and Peach PM (1951) Exchangeability of soil potassium in sand, silt and clay fractions as influenced by the nature of complementary exchangeable cations. Soil Sci. Soc. Am. J. 15: 125-128.

Oslen SR, Cole CV, Watanabe FS and Dean LA (1954) Estimation of Available Phosphorus in Soils by Extraction with Sodium 
Bicarbonate. US Department of

Agriculture, Washington.

Pandeya SC, Puri GS and Singh JS (1968)

Research Methods in Plant

Ecology. Asia Publishing House,

Bombay, India.

Ram SS, Dipesh R, Upendra B, Lekhendra

T, Ranjan A, Sushma D and Prakriti S (2015) Physicochemical characteristics of soil along an altitudinal gradients at southern aspect of ShivapuriNagarjun National Park, Central Nepal. Int. Res. J. Earth Sci. 3 (2): 1-6.

Rawat DS, Tiwari P, Das SK and Tiwari JK (2020) Tree species composition and diversity in montane forests of Garhwal Himalaya in relation to environmental and soil properties. J. Mt. Sci. 17 (12): 3097-3111.

Saha S, Rajwar GS and Kumar M (2018) Soil properties along altitudinal gradient in Himalayan temperate forest of Garhwal region. Acta Ecol. Sin. 38 (1): 1-8.

Semwal S (2006) Studies on Phytosociology, Diversity Patterns and Competition along an Altitudinal Gradient in a Part of Lesser Himalaya, Garhwal,
Uttarakhand. $\mathrm{PhD}$ Thesis, HNB Garhwal University, Srinagar (Garhwal), Uttarakhand.

Sharma CM, Baduni NP, Gairola S, Ghildiyal SK and Suyal S (2010) Effects of slope aspects on forest compositions, community structures and soil properties in natural temperate forests of Garhwal Himalaya. J. For. Res. 21 (3): 331-337.

Sheikh MA and Kumar M (2010) Nutrient status and economic analysis of soils in oak and pine forests in Garhwal Himalaya. J. Am. Sci. 6 (2): 117-122.

Tiwari SC (2005) Concepts of Modern Ecology. Bishen Singh Mahendra Pal Singh, Dehradun, India.

Thakur U and Bisht NS (2020) Physicochemical properties of soil in a protected area network (Chur Peak): Churdhar Wildlife Sanctuary in Western Himalaya, India. Plant Arch.20 (2): 75337542.

Walkley A (1947) An estimation of methods for determining organic carbon and nitrogen in soils. $J$. Agr. Sci. 25: 598-609. 